\title{
FATHOM
}

\section{Carbon Identity: A Lawrencian Reading of Thomas Hardy's Novels}

Une identité de carbone : lecture lawrencienne des romans de Thomas Hardy

\section{Giuseppina Di Gregorio}

\section{(2) OpenEdition}

\section{Journals}

\section{Electronic version}

URL: http://journals.openedition.org/fathom/712

DOI: $10.4000 /$ fathom.712

ISSN: 2270-6798

\section{Publisher}

Association française sur les études sur Thomas Hardy

\section{Electronic reference}

Giuseppina Di Gregorio, "Carbon Identity: A Lawrencian Reading of Thomas Hardy's Novels », FATHOM [Online], 4 | 2016, Online since 15 October 2016, connection on 19 April 2019. URL : http:// journals.openedition.org/fathom/712 ; DOI : 10.4000/fathom.712

This text was automatically generated on 19 April 2019 


\title{
Carbon Identity: A Lawrencian Reading of Thomas Hardy's Novels
}

Une identité de carbone : lecture lawrencienne des romans de Thomas Hardy

\author{
Giuseppina Di Gregorio
}

\section{The Study of Thomas Hardy: an introspective analysis}

\author{
Hardy and Lawrence have an unusual relationship in that each is a shaping \\ influence on the writings of the other. Whereas Hardy's influence on Lawrence is \\ direct and well attested, the younger man's influence is not on Hardy himself but \\ on how aspects of his novels came to be discussed, after both men were dead, in the \\ light (and sometimes the shadow) cast by Lawrence's Study of Thomas Hardy. \\ (Herbert, 449)
}

In his essay, Michael Herbert recognizes the pivotal role played by The Study, which has been defined by Robert Langbaum as a "curious little book" (Langbaum 1985, 69), highlighting its controversial nature. In fact, since this book is "a mixture of literary criticism with metaphysics, autobiography, cultural history and other things" (69), it provides a new frame of reference to reread and interpret Thomas Hardy's novels, but at the same time it also leads to a misreading of the same novels, in an attempt to identify the true meaning of Lawrence's own works. Like every work that is in fieri, Lawrence's book is marked by contradictions, but each part of his analysis, each element of his reasoning, becomes a part of a coherent whole when it is interpreted according to the set of values provided by the same writer. For this reason, it is illogic to interpret Lawrencian works according to traditional morality, since these works were produced using a "method of breaking conventions, of transgression, by the carnivalesque subversion of orthodox hierarchies" (Comellini, 18).

2 In order to appreciate D. H. Lawrence's analysis of the Wessex novels, it is necessary to consider the section of The Study that was edited by Anthony Beal in Selected Literary Criticism, published by Mercury Books in 1961, which is an extract of three different chapters (III, V and IX) ${ }^{1}$. As stated by some scholars, this section deals specifically with Thomas Hardy's novels, while the other sections are devoted to the discussion of 
Lawrence's aesthetics. This statement should be reconsidered, since it would imply a limited perspective and a partial interpretation: this work is not composed of two different analyses. There is one single reflection process that is structured according to several phases, and this interpretation is supported by R. Langbaum's study, who argues that there exists a true absorption of Hardy's writings in Lawrence's work.

Moreover, it should be taken into account that, from the point of view of the young writer, literary production is not doomed to adhere to predetermined patterns, because philosophies are

[...] deduced from the novels and poems, not the reverse. The novels and poems come unwatched out of one's pen. And then the absolute need which one has for some sort of satisfactory mental attitude towards oneself and things in general makes one try to abstract some definite conclusions from one's experience as a writer and as a man. The novels and poems are pure passionate experience. (Lawrence 2005, 57)

\section{A new ego in the novels of Thomas Hardy}

The importance of the Nottingham writer's epistolary relationships has been acknowledged by several eminent scholars ${ }^{2}$, and, even for those who do not agree with criticism on Lawrencian production, it is impossible to deny their relevance. The letters cover the entire span of his life and provide an insightful perspective to delineate the development of his writing, anticipating and at the same time making explicit the paths he follows in his novels.

Soon after Lawrence's death, it is Aldous Huxley who is the first to perceive the paramount value of this production, writing that

[...] I suggested to her [Frieda Lawrence] the following idea - that we should intersperse the letters with personal recollections of Lawrence by various people who have known him at different epochs of his career... In this way one should produce, it seems to me, a very living book - DHL in his own words and as reflected by the people (mostly interesting personalities) he knew. (Boulton xxv)

Moreover, despite the variety of occasions to which these letters are linked and the heterogeneity of the addressees, laying aside considerations about Lawrence's spontaneity, Boulton argues that,

True to his origins and personality, Lawrence abhorred 'English detachment'; he associated it with 'mere indifference and lack of life', and a reluctance to speak plain truth in plain words [...]. His epistolary prose responded to the impulses of dominant, even if temporary, feeling; its diction is assertively colloquial; its rhythms are those of everyday, often unpolished speech.

6 Taking into account the main characteristics of the epistolary production, this analysis of Hardyan novels moves from a letter of 5 June 1914, addressed to Edward Garnett, later defined as the carbon identity letter, due to its pivotal content. In this letter, Lawrence explains:

My theme is carbon. [...] That which is physic - non-human, in humanity, is more interesting to me than the old-fashioned human element - which causes one to conceive a character in a certain moral scheme and make him consistent. (Huxley 197)

[...] you mustn't look in my novel for the old stable ego of the character. There is another ego, according to whose action the individual is unrecognizable, and passes through, as it were, allotropic states which it needs a deeper sense than any we've 
been used to exercise, to discover are states of the same single radically unchanged element. (Huxley 198)

The new ego to which he refers is an impersonal identity, something that lies under the epidermis, a region where true actions take place - the unconscious. This new perspective allows the writer to gain a deep understanding of human lives, thus delineating characters that cannot be described according to old patterns, because they are inconsistent, ephemeral traces of ever evolving identities. Referring to the required deeper sense, it could be contended that this new identity, carbon, is more valuable than the ordinary diamond, because it is hidden and cannot be detected without the support of specific tools, a research work. For this reason, Lawrence states that

[...] diamond and coal are the same pure single element of carbon. The ordinary novel would trace the history of the diamond - but I say, 'Diamond, what! This is carbon'. (Huxley 198)

8 According to Langbaum, this specific reference to the inanimate represents a step forward compared to what Thomas Hardy achieved, since the latter had tracked down his characters' roots in the vegetal world. Behind these results, there is a common Wordsworthian matrix: the Romantic poet was one of the first to use backgrounds in order to provide his characters' selves with greater intensity. Consequently, it is possible to argue that the true innovation, outlined by Wordsworth and developed by Hardy and Lawrence through the sexualisation of landscape, is represented by "the portrayal of characters as states of being rather than as defined by social class and moral choice" (Langbaum 1997, 77), which were the criteria of traditional characterization.

9 In The Study of Thomas Hardy, Lawrence analyses several characters portrayed by the Victorian writer, pointing out that their behaviours are not determined by social conventions. In describing them, he refers to their actions using the adjective explosive and the adverb suddenly, in order to highlight the lack of possibilities to foresee their actions or to determine the reasons behind them. In fact,

Nowhere, except perhaps in Jude, there is the slightest development of personal action in the characters: it is all explosive... The rest explode out of the convention. They are people each with a real, vital, potential self... and this self suddenly bursts the shell of manner and convention and commonplace opinion, and acts independently, absurdly; without mental knowledge or acquiescence. And from such an outburst the tragedy usually develops. For there does exist, after all, the great self-preservation scheme [society], and in it we all live. (Lawrence 1961, 167)

From the point of view of readers, characters' choices appear as illogical, and this is due to the fact that real actions take place out of the reach of mind, where it is impossible to perceive underlying motivations from the outside: these are located in the region of the unconscious, hence the tendency of the two writers, both Hardy and Lawrence, to treat "their characters' social selves - the whole concern of the novel of manners - as the mere tip of the iceberg" (Langbaum 1985, 77).

11 The actions performed by heroes and heroines that inhabit Thomas Hardy's novels are part of the broader framework of the struggle to be, or rather to become complete. The possibility to reach this state depends on the ability to mend the tear between the selfpreservation purpose and the creative purpose (Langbaum 1997, 70): this implies the abandonment of a predetermined scheme in which characters are trapped. Unfortunately, the scheme is part of themselves, and consequently, from the outset, any attempt is doomed to failure ${ }^{3}$. D. H. Lawrence describes this self-preservation scheme as a fortified city from which people want to escape because they feel oppressed, but at the 
same time to live inside represents the only possibility of life (Casagrande 41). It is the product of social conventions and what individuals can do is adapt themselves to these conditions and sacrifice their potential, or venture outside the walls, knowing that they are doomed to succumb under the weight of the rejection of community or for a lack of their forces. This double opportunity translates the abovementioned tear and represents tragedy: it originates because the inner being of these men and women "bursts the shell of manner and convention and commonplace opinion" (Lawrence 1961, 168). An external conflict that becomes an inner one, since social dimension is a part of human beings: in fact, as Lawrence writes about one of Hardy's male characters,

[...] first, that he is a member of the community, and must, upon his honour, in no way move to disintegrate the community, either in its moral or its practical form; second, that the convention of the community is a prison to his natural, individual desire, a desire that compels him, whether he feel justified or not, to break the bounds of the community, lands him outside the pale, there to stand alone [...]. (Lawrence 1961, 168)

This conflict constitutes one of the Wessex novels' themes: it is a gradual process of becoming aware of human beings' fragmentation, as Lawrence writes, "this is the tragedy and only this: it is nothing more metaphysical than the division of a man against himself" (Lawrence 1961, 168). The main problem is to find a way to live within what characters would like to abandon and to destroy. Comparing modern tragedy to the past, Lawrence discovers a contrasting element: modernity's inherent weakness. In fact, while great heroes such as Hamlet or Macbeth fight against "the great unwritten morality of nature" (177), Hardy's characters, as well as those delineated by Tolstoi, transgress common morality. In the first case, this transgression implied a punishment, while in the second one, in modern tragedy, common morality permeates the background, playing a passive role: characters are not directly punished, even if the result of their actions is failure. This is the reason why modern tragedy belongs to an inferior rank: deities of the past are replaced by a set of social conventions that determine human life.

According to Lawrence,

[...] this is the quality Hardy shares with the great writers, Shakespeare or Sophocles or Tolstoj, this setting behind the small action of his protagonists the terrific action of unfathomed nature; setting a smaller system of morality, the one grasped and formulated by the human consciousness within the vast, uncomprehended and incomprehensible morality of nature or of life itself, surpassing human consciousness. (Lawrence 1961, 177)

Moreover, he adds that

[...] the vast, unexplored morality of life itself, what we call the immorality of nature, surrounds us in its eternal incomprehensibility, and in its midst goes on the little human morality play, with its queer frame of morality and its mechanised movement; seriously, portentously, till some one of the protagonists chance to look out of the charmed circle, weary of the stage, to look into the wilderness raging out. (Lawrence 1961, 177)

14 Lawrence describes human life as a little lit circle dominated by a wild penumbra, as Langbaum writes (73), which is immutable, hence the absurd claim that small human actions can, albeit minimally, modify it and divert its course. Analysing The Return of the Native, he writes about these characters:

They are one year's accidental crop. What matters if some are drowned or dead, and others preaching or married: what matters, any more than the withering heath, the reddening berries, the seedy furze, and the dead fern of autumn one of Egdon? The Heath persists. Its body is strong and fecund, it will bear many more 
crops beside this. Here is the sombre, latent power that will go on producing, no matter what happens to the product (Lawrence 1961, 172). to explain the apparent contradiction. The first hypothesis deals with the seed of death that is part of themselves, while the second one is related to what Lawrence considers as Hardy's revenge. Both of them are true, and strictly linked if we consider the late Victorian context: in fact, according to the bourgeois morality, which their creator embodies, exceptional people must be negative, hence their destruction. For this reason the writer chooses individuals with specific weaknesses. However, the choice operated by Hardy is not a free one, since he is forced to take this position because he represents the community's interests, and therefore he must condemn exceptions. Making this choice implies that "he must go against himself. His private sympathy is always with the individual against the community: as is the case with the artist" (Lawrence 1961, 183).

These results concern a synchronic development of Lawrence's analysis, but if we consider the diachronic perspective, it is possible to detect a shift concerning Thomas Hardy's judgment. If in the early works, there is a total condemnation of the villain of the story, later there is a sort of humanization process and the same place is gradually occupied by the Virgin Knight or White Virgin. This does not mean that negative characteristics are assimilated by good heroes; on the contrary, it is a true change of place, "it is a complete and devastating shift-over, it is a complete volte-face of moralities. Black does not become white, but it takes White's place as good; white remains white, but it is found bad" (Lawrence 1961, 181). To explain this concept, it is pivotal to consider the figure of Angel Clare in Tess of the d'Urbervilles. According to the bourgeois morality, he should be the good protagonist, the white knight as opposed to the black knight represented by Alec d'Urberville. From this point of view, he is a victim of the events, a hero who succumbs to the evil forces and he could be compared to Tess. Oddly

FATHOM, 4 | 2016 
enough, D. H. Lawrence detects the same evil forces within the character himself. In Phoenix, he writes that "if we want to find the real enemy to-day, here it is: idealism" (Salter 64): idealism represents Clare's negativity, because it is detrimental for himself and people who live with him, as for example Tess. He loves his idea of Tess, something that is within himself; he does not recognize her as a separate human being: according to Lawrence, otherness is pivotal in a relationship between man and woman, because it allows an exchange of energy between the two parts. Destruction occurs because idealism leads to a stable condition, and absence of movement is considered negatively. The greatest flaw of Hardy's characters consists in their being impotent to be, because being implies a constant change. Analysing Clym in The Return of the Native, as Langbaum points out, Lawrence writes that he is impotent to be, implying that

[...] he must transform himself, and live in an abstraction, in a generalization, he must identify himself with the system. He must live as Man or Humanity, or as the Community, or as Society, or as Civilization. ... He already showed that thought is a disease of the flesh, and indirectly bore evidence that ideal physical beauty is incompatible with emotional development and a full recognition of the coil of things. (Langbaum 1997, 73)

19 Therefore, Angel's rigidity is completely wrong, since, using K. W. Salter's words (Salter 64 ), this rigidity is the most dangerous form of corruption, because the combination of mental consciousness and a strong will is a principle of death. This is a condition of nonlife, which is reached because Christian religion is fossilized, something already arranged, unable to follow life's changes. Moreover, this condition is further complicated when we take into account that idealism also leads to a sexual deficiency, something that prevents human beings from having a chance to approach 'the unknown'. ${ }^{4}$ This concept can be related to that of virginity, treated by Thomas Hardy as a pathological mental state, although not explicitly, thus highlighting the breaking point between the writer and Victorian tradition. As in the case of Sue in Jude the Obscure, the condition can determine self-destruction. Consequently, if the behaviour of the hero/heroine is condemned, also the villain is not spared: in fact, even if Alec seems to be more appreciated by both of the writers, he shows the same inability to develop. Considering the following examples, in order to clarify the multifaceted bond between Hardy and his characters, it is possible to refer to Lawrence's words:

Hardy first makes a characteristic comment, the comment of the external observer, who seems to speak with detachment [...], seems to dissociate himself from the judgement on Clare that the reader is surely making [...]. (Salter 64)

In Tess of the d'Urbervilles for example, Hardy writes about Angel that, "Some might risk the odd paradox that with more animalism he would have been the nobler man. We do not say it. Yet Clare's love was doubtless ethereal to a fault, imaginative to impracticability." (Hardy 292)

According to Lawrence, Hardy had a wonderful sensuous understanding, thus proving to be much closer to the twentieth century, and especially to Lawrence himself, than to the Victorian society. As Langbaum writes, even if "Hardy is still a social reformer, still out to free us from the bonds of established institutions" (Langbaum 1997, 73), in his characters it is possible to detect those traces of carbon described by Lawrence, the underestimated unconscious: accidents suffered by his characters actually represent "an advanced technique for making an external event confirm an unconscious desire" (Langbaum 1985, 80). In Tess for example, the chance that does not allow her to confess her past to Angel represents an unconscious desire, it is 


$$
\text { humanity to its purpose, as the tide sways the helpless weed, was not to be controlled by }
$$
vague lucubrations over the social rubric [...]. (Langbaum 1985, 82)

Tess embodies the conflict between this unconscious desire to satisfy her nature and the awareness that she is unable to do this. She has a strong sexual desire that, if satisfied, would have taken her to the status of complete human being: she represents the sexual - creative purpose, which is part of the wider biological purpose betrayed by human beings. caesura with the Victorian tradition and a link to the younger writer; however, there are several aspects that deserve an in-depth analysis. In fact, the innovativeness of Hardy does not reside in the treatment of the subject of sex itself, but in the mode used to achieve this goal: sex becomes "self-justifying, that is not subject to judgment by other values - but is indeed the source of other values" (Langbaum 1985, 71). Lawrence inherits this attitude, as well as a second theme, that of the unconscious. The main difference between the two writers is represented by the period in which they live: if Hardy lives in a society where there are values that he can criticize, Lawrence's days are different, because it is a society without values, no longer suitable for novels.

Lawrence also inherits something else from the Hardyan lessons, or it would better to say that he learns something, as stated by M. Kinkead-Weekes: the need and the danger of some metaphysics, which is nothing more than a given system of morality, to which works of art have to adhere. In fact, while showing that morality has a value that is related to the period that produces it, it is impossible to deny that the artistic product depends on a theory of being and knowing. It is based on the different answers that humans can give to the antinomy between Love and Law, Flesh and Spirit, Father and Son: these antinomies are those principles that underpin our lives, and the different answers determine various human attitudes. Lawrence, however, warns against some possible misleading inferences. A true work of art contains the critique of the morality to which it adheres, and it is the extent to which it is criticized to determine its value. However, it cannot be stated that the perfect adherence to a metaphysic is the only principle to recognize a work of art: there may be cases in which any possibility of an artistic form is precluded by excessive adherence to the latter. Above all, Lawrence makes it clear that "each work of art has its own form, which has no relation to any other form" (Lawrence 1961, 186).

Comparing the ancient tragedy to the modern one, the Nottingham writer focuses his attention on Euripides and Aeschylus. The representations that both of them provide concerning the abovementioned dichotomies are very different: the one provided by Aeschylus is balanced, representing the star equilibrium theorized by Lawrence, which consists of principles with equal force, two in one, eternally struggling to be eternally reconciled. Euripides' work, on the other hand, provokes audience disbelief because it brings to the stage a weaker principle than the other: in particular, Love is doomed to failure.

According to Lawrence, Thomas Hardy repeats the same mistake: in his work, there is no reconciliation between Love and Law, since the Victorian writer believes that the spirit of Love must always succumb under the blind and stupid power of the Law, simply because this is stronger. The potential danger is that a metaphysical scheme could be misused to justify the writer's mistakes, so that the world is adapted to the latter and not the

FATHOM, 4 | 2016 
reverse, as it should be. Although he recognizes that Hardy has no equals throughout the English literary tradition, he describes his system as follows:

[...] if it were not that man is much stronger in feeling than in thought, the Wessex novels would be sheer rubbish, as they are already in parts [...] for nothing in his work is so pitiable as his clumsy efforts to push events into line with his theory of being, and to make calamity fall on those who represent the principle of love. (Lawrence 1961, 189)

The intransigence that permeates Lawrence's analysis of the work of Thomas Hardy is due to the fact that he recognizes a special function of fiction:

It is the novelists and dramatists who have the hardest task in reconciling their metaphysic, their theory of being and knowing, with their living sense of being. Because a novel is a microcosm, and because man in viewing the universe must view it in the light of theory, therefore every novel must have the background or the structural skeleton of some theory of being, some metaphysic. But the metaphysic must always subserve the artistic purpose beyond the artist's conscious aim. Otherwise the novel becomes a treatise. (Lawrence 1961, 188)

\section{Conclusion: towards some new metaphysics}

"One man isn't any better than another, not because they are equal, but because they are intrinsically other, that there is no term of comparison." (Lawrence 1996, 125) Lawrence writes these words in Women in Love, and it is not possible to determine whether he refers to his own work or to writers in general, but these words can be considered as part of a true interior process of awareness: the one that informs The Study of Thomas Hardy.

As explained by Catherine Carswell, Lawrence was appointed to write a book on his illustrious predecessor by the editor Nisbet, which was working on a project named Writers of the Day, by Bertram Christian. It is the same Christian who decided to contact Lawrence, referring to a sort of fondness towards his forerunner: but this work was never published because, as Allendorf writes, "(though containing some good criticism of Hardy's novels) [it] turned out to be more preoccupied with his own ideas than with Hardy's novels." (Allendorf 467)

Regardless of the perspective that readers decide to adopt, or what critics argue, it is possible to assure that The Study reveals a deep understanding and assimilation of Thomas Hardy's themes. Nowadays, there are two different approaches in reading the Wessex novels: the first one is the Victorian or moralistic manner, while the second is the Lawrencian or psychological approach. Lawrence not only appreciates the revolutionary impact of his forerunner's works, hidden behind a thick layer of common morality for the middle class, but goes further, placing himself in line with his precursor, in order "to complete him, to continue his direction, to fulfil the implications of Hardy's art that Hardy as a Victorian could not fulfil" (Langbaum 1997, 69).

Inheriting the subordination of the conscious to the unconscious, aware of the dangers of adopting a metaphysics, D. H. Lawrence moves from Thomas Hardy's experience to develop the concepts of wholeness and otherness ${ }^{5}$ through a dynamic process, to operate a reconciliation of opposite purposes, leaving to future generations the most accurate analysis of the humankind and the best psychological insights. As Michael Herbert writes, "Lawrence's Hardy is by no means the only Hardy, but remains the most individual, idiosyncratically insightful, and influential response to the people in Thomas Hardy's novels." (Herbert 457) 


\section{BIBLIOGRAPHY}

Alcorn, John, The Nature of Novel from Hardy to Lawrence, London: Macmillan, 1977.

Aldington, Richard, D. H. Lawrence: Portrait of a Genius But..., New York: Collier Books, 1961.

Allendorf, O., "The Origin of Lawrence's 'Study of Thomas Hardy”, Notes and Queries 17:12

(December 1970): 466-467.

Beards, Richard D., “D. H. Lawrence and 'The Study of Thomas Hardy', His Victorian

Predecessor", D. H. Lawrence Review 2 (Fall 1969): 210-229.

Boulton, James T., The Selected Letters of D. H. Lawrence, New York: Cambridge University Press, 2000 .

Casagrande, Peter J., Hardy's Influence on the Modern Novel, Basingstoke and London: Macmillan, 1987.

Comellini, Carla, D. H. Lawrence - A Study on Mutual and Cross References and Interferences, Bologna: Club, 1995.

Ebbatson, Roger, The Evolutionary Self: Hardy, Forster, Lawrence, New York: Harvester Press, 1982.

Di Gregorio, Giuseppina, State of Soul - L'immaginario di D. H. Lawrence in 'The Study of Thomas Hardy', Lugano: Agorà \& Co., 2014.

Hardy, Thomas, Tess of the D'Urbervilles, London: Harper Press, 2010.

Herbert, Michael, “Lawrence's Hardy”, ed. Phillip Mallett, Thomas Hardy in Context, New York: Cambridge UP, 2013.

Hoffman, Russell, The Idea of the Unconscious in the Novels of Thomas Hardy, Berkley: University of California, 1963.

Huxley, Aldous (ed.), The Letters of D. H. Lawrence, London: Heinemann, 1956.

Kinkead-Weekes, Mark, "Lawrence on Hardy”, ed. Lance St John Butler, Thomas Hardy after Fifty Years, London: Macmillan, 1977.

Langbaum, Robert, Thomas Hardy in Our Time, New York: St. Martin's Press, 1997.

Langbaum, Robert, "Lawrence and Hardy”, ed. Jeffrey Meyers, D. H. Lawrence and Tradition, Amherst: UP of Massachusetts, 1985.

Lawrence, D. H., Selected Literary Criticism, ed. A. Beal, London: Mercury Books, 1961.

Lawrence, D. H., Psychoanalysis and the Unconscious (1921) \& Fantasia of the Unconscious (1922), Mineola, NY: Dover Publications, 2005.

Lawrence, D. H., Women in Love (1921), Harmondsworth: Penguin Popular Classics, 1996.

Mallett, Phillip, The Achievement of Thomas Hardy, New York: Palgrave Macmillan, 2000.

Paterson, John, "Lawrence's Vital Source: Nature and Character in Thomas Hardy”, ed. U. C.

Knoepflmacher and G. B. Tennyson, Nature and the Victorian Imagination, Berkeley: University of California Press, 1977.

Salter, Keith William, “Lawrence, Hardy, and 'The Great Tradition”, in English 22 (1973): 60-65. 
Thomas, Jane, Thomas Hardy and Desire: Conceptions of the Self, Basingstoke: Macmillan, 2013.

\section{NOTES}

1. Published for the first time in 1936 by E. McDonald.

2. See for example The Selected Letters of D. H. Lawrence edited by James T. Boulton.

3. As for example in Tess of the d'Urbervilles. The protagonist strives to improve her life, but each attempt fails, because social conventions are part of herself, and it is impossible to break them without damaging her entire self.

4. According to D. H. Lawrence, through sexual intercourse, men and women have the possibility to exchange vital energy, and, thanks to the acknowledgement of otherness, to approach the unknown.

5. For a more accurate analysis of Lawrence's imagery, refer to Di Gregorio, State of Soul L'immaginario di D. H. Lawrence in 'The Study of Thomas Hardy'.

\section{ABSTRACTS}

The Study of Thomas Hardy is one of the most misunderstood Lawrencian works, but at the same time it is one of the most influential. Hardy is not a mere pretext that the writer uses to discuss his metaphysics and aesthetics - as many critics have claimed: Lawrence writes on Hardy in order to understand himself. A subtle analysis of the Wessex novels allows him to name the new subject he attempts to describe, the unconscious. In the famous "carbon identity letter", D. H. Lawrence detects a chemical element that is more valuable than the diamond itself, because it represents the true nature of human beings, something that underlies their actions and feelings, which is "non-human, in humanity": an unrecognizable ego. According to Virginia Woolf, there is "a little blur of unconsciousness" in Hardy's Novel, as if he were not cognizant of the implications of his writing, leaving "for his readers to make out his full meaning and to supplement it from their own experience". From Thomas Hardy's lesson, Lawrence learns the worth and the danger of metaphysics, inheriting the two great themes that shape his literary production, the human psyche and sexual dimension. The bound that ties these two eminent writers is deeper than a simple relation between master and disciple: both of them break with tradition and produce better works when the unconscious drives their actions. The aim of this paper is to analyze the complex relationship, shedding new light on Hardy's novels in order to appreciate his "state of soul".

L'Étude sur Thomas Hardy est l'une des œuvres les plus incomprises de D. H. Lawrence. Hardy n'est pas un simple prétexte pour parler de sa métaphysique et de son esthétique, comme certains critiques l'ont prétendu : Lawrence écrit sur Hardy afin de se comprendre lui-même. Son analyse subtile des romans du Wessex l'aide à nommer le nouveau sujet qu'il veut décrire, à savoir l'inconscient. Dans la célèbre Lettre sur l'identité de carbone, D. H. Lawrence met au jour un élément chimique plus précieux que le diamant lui-même, car il représente la véritable nature des êtres humains. Il s'agit de quelque chose qui sous-tend toutes nos actions et tous nos sentiments, quelque chose qui n'est "pas humain dans l'humanité” : un ego méconnaissable. Selon Virginia Woolf, il y a "un petit flou d'inconscience" dans les romans de Hardy, comme si l'auteur "lui- 
même n'était pas conscient de ce qu'il a fait [...], laissait à ses lecteurs le soin de déchiffrer la signification complète et de la compléter à partir de leur propre expérience". De la leçon hardyenne, Lawrence apprend la valeur et le danger de la métaphysique et hérite des deux grands thèmes de sa production littéraire : le sexe et l'inconscient. Le lien qui unit Lawrence et Hardy est plus profond qu'une simple relation de maitre à disciple : tous deux rompent avec la tradition et produisent de meilleures œuvres quand l'inconscient les guide. Le but de cet article est d'analyser leur relation afin de comprendre la dette profonde de Lawrence à l'égard de Hardy, ainsi que d'éclairer autrement les romans de Hardy pour évaluer "l'état d'âme" de l'auteur.

\section{INDEX}

Keywords: humanity, Lawrence (D. H.), unconscious, metaphysics, identity, morality, tragedy, sexuality

Mots-clés: humanité, Lawrence (D. L.), inconscient, métaphysique, identité, moralité, tragédie, sexualité

\section{AUTHOR}

\section{GIUSEPPINA DI GREGORIO}

Giuseppina Di Gregorio is an English Lecturer at the University of Catania (Economics and Business Department). She holds a PhD in English and Anglo-American Studies, with a thesis about Neo-Victorian Novels (about the novels of C. Priest and P. Ackroyd). She wrote a book entitled State of Soul - L'immaginario di D. H. Lawrence in The Study of Thomas Hardy. Her research interests include Victorian Studies (especially Victorian novels); Postmodern Biofictions; Translation Studies and English for Specific Purposes (Business English). 